Marcin Jamroży*

\title{
Dochody z działalności gospodarczej- analiza stanu obecnego i możliwe kierunki zmian
}

\begin{abstract}
Income from business activity. Current status and directions for change: The article provides an analysis of the current income taxation model in Poland with regard to business activity. The rationale behind the call for change is the erosion of tax base, which can be seen particularly in the activities of related entities and the so-called aggressive tax planning. The author discusses the current regulatory framework and proposes alternatives, particularly solutions relating to the duality in income taxation of commercial companies, lump-sum taxation forms, rules determining tax base, tax valuation of transactions, as well as taxation of business restructuring.
\end{abstract}

Słowa kluczowe: dochód z działalności gospodarczej - erozja bazy podatkowej · wycena podatkowa $\cdot$ restrukturyzacja biznesowa $\cdot$ zryczałtowane formy opodatkowania

Keywords: business income $\cdot$ erosion of tax base $\cdot$ tax valuation $\cdot$ business restructurings · lump-sum taxation forms

* Doktor hab. nauk ekonomicznych, profesor nadzwyczajny w Zakładzie Podatków Instytutu Finansów Szkoły Głównej Handlowej w Warszawie; e-mail: mjamro@sgh.waw.pl.

\section{Wstęp}

Zmiany w prawie podatkowym są naturalnym, ale i koniecznym procesem dostosowania systemu do zmieniającego się otoczenia, spowodowanym ciągłymi przemianami w gospodarce, życiu społecznym, polityce czy prawie. Zmiany mogą przyjmować postać reformy ${ }^{1}$ lub aktualizacji (zmian dostosowawczych) systemu podatkowego. Obecnie mamy głównie do czynienia ze zmianami do-

${ }^{1}$ Szerzej na ten temat reformy podatkowej zob. B. Brzeziński, Reformy podatkowe - teoria i doświadczenia polskie [w:] Systemowa reforma podatków dochodowych, red. B. Brzeziński, W. Nykiel, C.H. Beck, Warszawa 2009, s. 3; Dylematy reformy systemu podatkowego w Polsce, red. H. Dzwonkowski, J. Kulicki, Wydawnictwo Sejmowe, Warszawa 2016. 
stosowawczymi (tzw. uszczelnianiem systemu podatkowego), które charakteryzuje przede wszystkim wycinkowość, a ich wprowadzanie następuje pod wpływem zaszłości w obszarze koniunktury gospodarczej². Okolicznością, która $\mathrm{w}$ znacznym stopniu determinuje potrzebę zmian $\mathrm{w}$ opodatkowaniu dochodów, jest erozja bazy podatkowej, której upatruje się zwłaszcza w działalności podmiotów powiązanych oraz wykorzystywanych technikach tzw. agresywnego planowania podatkowego ${ }^{3}$. Skutkują one (relatywnym) spadkiem dochodów budżetowych.

Ucieczka od podatku może następować w wyniku legalnego, lecz sztucznego kształtowania sytuacji podatkowej podatników (unikanie opodatkowania), względnie uchylania się od opodatkowania (oszustw podatkowych) ${ }^{4}$. Ucieczka od podatku dochodowego pozwala podatnikom na zwiększenie zysków netto przez minimalizację opodatkowania, a z perspektywy interesów budżetowych państwa prowadzi do zmniejszenia wpływów do budżetu państwa, narusza zasadę równości opodatkowania, obniża też prestiż państwa i prawa ${ }^{5}$.

Również z powodu postępującej komplikacji stosunków biznesowych w skali międzynarodowej tradycyjny sposób opodatkowania niektórych zjawisk lub procesów gospodarczych powoli wyczerpuje się. Globalizacja i umiędzynarodowienie procesów tworzenia wartości dodanej ze wszelkimi ich konsekwencjami (międzynarodowa optymalizacja podatkowa, w tym również działania o charakterze agresywnym) są procesami wyprzedzającymi konstrukcje zawarte w poszczególnych systemach podatkowych. Sygnalizuje się jedynie, że problematyka związana ze zmniejszaniem się wpływów podatkowych stała się na tyle istotna, że przeciwdziałanie erozji podstawy opodatkowania jest przedmiotem ożywionej debaty na forach Komisji Europejskiej, Organizacji Współpracy Gospodarczej i Rozwoju (OECD) czy też grupy G20. W październiku 2015 r. zostały opublikowane końcowe raporty OECD w ramach planu działań pt. Action Plan on Base Erosion and Profit Shifting (Erozja bazy podatkowej oraz przenoszenie zysków, BEPS) ${ }^{6}$, zawierające listę konkretnych

${ }^{2}$ B. Brzeziński, Reformy podatkowe - teoria i doświadczenia polskie, op. cit., s. 3-4.

3 O optymalizacji i zarządzaniu podatkami zob. szerzej M. Jamroży, S. Kudert, Optymalizacja opodatkowania dochodów przedsiębiorstw, Wolters Kluwer, Warszawa 2013; J. Szlęzak-Matusewicz, Zarządzanie podatkami osób fizycznych, Wolters Kluwer, Warszawa 2013.

${ }^{4} \mathrm{Na}$ temat przesłanek ucieczki od podatku zob. np. J. Ickiewicz, Podatki. Składki. Opłaty. Fiskalne obciążenia działalności gospodarczej, Oficyna Wydawnicza SGH, Warszawa 2014, s. 33 i n.; J. Gałuszka, Korupcja i szara strefa wobec polityki gospodarczej państwa [w:] Konsekwencje zmiany obciążeń podatkowych w Polsce, red. J. Głuchowski, K. Piotrowska-Marczak, J. Fila, Difin, Warszawa 2013, s. 265-289.

${ }^{5}$ Zob. z dalszymi odesłaniami M. Pietrewicz, P. Felis, M. Jamroży, J. Szlęzak-Matusewicz, Przesłanki $i$ kierunki zmian $w$ polskim systemie podatkowym - wybrane zagadnienia [w:] Rozwój nauki o finansach. Stan obecny i pożądane kierunki jej ewolucji, red. J. Ostaszewski, E. Kosycarz, Oficyna Wydawnicza SGH, Warszawa 2014, s. 363 i n.

6 Zob. http://www.oecd.org/tax/beps-2015-final-reports.htm. 
działań przeciwko tzw. agresywnej optymalizacji podatkowej ${ }^{7}$. Podejmowane przez polskiego ustawodawcę działania mają do tej pory głównie na celu tzw. uszczelnienie systemu podatkowego. Działania te są podyktowane również dostosowaniem do wskazanych inicjatyw ogólnoświatowych (unijna dyrektywa $\mathrm{ATAD}^{8}$, rekomendacje wynikające z BEPS) ${ }^{9}$. Analiza opodatkowania tzw. dochodów transgranicznych nie stanowi przedmiotu artykułu; wywód koncentruje się na aspekcie krajowym opodatkowania.

Opodatkowanie dochodu wynikającego z działalności gospodarczej, obarczonego relatywnie wysokim ryzykiem, ogranicza akumulację kapitału i osłabia tempo wzrostu gospodarczego. Postulat najdalej idący, tj. likwidacji opodatkowania zysków przedsiębiorstw, z uwagi na problemy z legitymizacją poboru, niską skuteczność fiskalną CIT (na poziomie ok. 7-11\% wpływów ogółem ${ }^{10}$ ) czy też relatywnie wysoką ekspozycją na manipulacje, nie jest również przedmiotem rozważań ${ }^{11}$. Podstawowym celem artykułu jest przedstawienie analizy stanu obecnego oraz kierunku reformy (względnie zasadniczych zmian dostosowawczych) $\mathrm{w}$ systemie opodatkowania dochodó $\mathrm{w}^{12} \mathrm{z}$ działalności gospodarczej w kluczowych obszarach.

7 Zgodnie z definicją przyjętą przez Komisję Europejską agresywne planowanie podatkowe polega na wykorzystywaniu aspektów technicznych systemu podatkowego lub rozbieżności między dwoma systemami podatkowymi lub większą ich liczbą w celu zmniejszenia zobowiązania podatkowego. Jego skutki obejmują podwójne odliczenia (np. w sytuacji, gdy ta sama strata jest odliczana zarówno w państwie źródła dochodu, jak i w państwie rezydencji) i podwójne nieopodatkowanie (np. w sytuacji, gdy dochód, który nie jest opodatkowany w państwie źródła dochodu, jest także zwolniony w państwie rezydencji); zob. zalecenia Komisji 2012/772/UE z 6 grudnia 2012 r. w sprawie agresywnego planowania podatkowego, Dz.Urz. UE L 338 z 12 grudnia 2012 r., s. 41.

8 Zob. dyrektywa Rady (UE) 2016/1164 z 12 lipca 2016 r. ustanawiająca przepisy mające na celu przeciwdziałanie praktykom unikania opodatkowania, które mają bezpośredni wpływ na funkcjonowanie rynku wewnętrznego, Dz.Urz. UE L 193 z 19 lipca 2016 r., s. 1.

9 Zob. także rezolucję z 8 czerwca 2010 r. w sprawie koordynacji zasad dotyczących przedsiębiorstw zagranicznych i niedostatecznej kapitalizacji w Unii Europejskiej (2010/C 156/01), zalecenia Komisji 2012/772/UE z 6 grudnia 2012 r. w sprawie agresywnego planowania podatkowego.

${ }_{10}$ Informacje o wpływach budżetowych na podstawie danych łącznych uzyskanych $\mathrm{z}$ izb celnych i izb skarbowych w podziale na lata zob. Ministerstwo Finansów, http://www. finanse.mf.gov.pl/budzet-panstwa/wplywy-budzetowe.

${ }^{11}$ Szerzej zob. F. Grądalski, Teoretyczne aspekty racjonalizacji systemu podatkowego [w:] Dorobek ekonomii, finansów i nauk o zarządzaniu oraz jego praktyczne wykorzystanie na przełomie XX i XXI wieku, red. R. Bartkowiak, J. Ostaszewski, Oficyna Wydawnicza SGH, Warszawa 2012, s. 571-580; idem, System podatkowy w świetle teorii optymalnego opodatkowania, Oficyna Wydawnicza SGH, Warszawa 2006.

12 Ustawa z 15 lutego 1992 r. o podatku dochodowym od osób prawnych, t.j. Dz.U. 2016, poz. 1888, ze zm.; dalej u.p.d.p.; ustawa z 26 lipca 1991 r. o podatku dochodowym od osób fizycznych, t.j. Dz.U. 2016, poz. 2032, ze zm.; dalej u.p.d.f. 


\section{Erozja bazy podatkowej}

Jako punkty wyjścia do dalszych rozważań przyjmuje się, na podstawie już samych zestawień porównawczych udostępnionych przez Ministerstwo Finansów oraz Główny Urząd Statystyczny, że w Polsce występuje problem związany ze zmniejszaniem się wpływów $\mathrm{CIT}^{13}$. W $2016 \mathrm{r}$. wpływy z tego podatku wynosiły prawie $34 \mathrm{mld}$ zl, a w okresie od 1 stycznia 2017 r. do 30 czerwca 2017 r. około $20 \mathrm{mld} \mathrm{zl}^{14}$. W latach 2007-2016 odnotowano stały wzrost liczby podatników, a także (z wyjątkami) wzrost zagregowanych dochodów podatników, jak również wzrost zyskowności podatników (począwszy od roku 2012), którym jednak nie towarzyszyło (odpowiednie) zwiększenie wpływów z tytułu CIT. Stanowi to pośredni dowód erozji bazy podatkowej. Warto też wskazać, że najniższy poziom tzw. efektywnej stopy podatkowej wystapił w latach 2005-2006 i wynosił 16,7\%, przy czym w ostatnich trzech badanych latach stopa ta wzrosła do poziomu 17,5\% w $2016 \mathrm{r}$.

Problem szacowania tzw. luki podatkowej CIT wymaga szczegółowych i pogłębionych badań analitycznych. Należy odnotować, że luka podatkowa CIT oszacowana na podstawie nieopublikowanego raportu na zlecenie Komisji Europejskiej pt. Analysis of the legal and tax situation of international and national holding companies operating in the member countries of the European Union between 2013-2015, wynosi około 10 mld euro ${ }^{15}$. Autorzy innego raportu ${ }^{16}$, R. Piekarz i A. Miarkowski, również potwierdzają występowanie erozji wpływów z CIT, łącząc je przede wszystkim z elastycznością dochodową międzynarodowych korporacji, a straty budżetu państwa oceniają na co najmniej $10 \mathrm{mld}$ zł.

\section{Dualizm opodatkowania dochodów spółek handlowych}

\section{Opodatkowanie dochodów spółek kapitałowych}

Dochód spółki kapitałowej (spółki z o.o. lub akcyjnej) podlega opodatkowaniu, stosownie do art. 19 ust. 1 u.d.p.p., według stawki 19\% względnie 15\% (obni-

${ }_{13}$ Zob. Ministerstwo Finansów, Informacja dotyczaca rozliczenia podatku dochodowego od osób prawnych za 2016 rok, http://www.finanse.mf.gov.pl/documents/766655/6153845/Informacja; Główny Urząd Statystyczny, Zweryfikowany szacunek produktu krajowego brutto za lata 2010-2015, https://stat.gov.pl/obszary-tematyczne/rachunki-narodowe/roczne-rachunki-narodowe/zweryfikowany-szacunek-produktu-krajowego-brutto-za-lata-2010-2015,9,2.html.

${ }^{14}$ Odnośnie do wpływów budżetowych na podstawie danych łącznych uzyskanych $\mathrm{z}$ izb celnych i izb skarbowych w podziale na lata zob. Ministerstwo Finansów, http://www. finanse.mf.gov.pl/budzet-panstwa/wplywy-budzetowe.

15 Za „Rzeczpospolitą” z 16 marca 2017 r., http://www.rp.pl/Budzet-i-Podatki/ 303169813-Ponad-40-mld-zl-luki-w-podatku-CIT.html\#ap-1.

16 Zob. R. Piekarz, A. Miarkowski, Raport 1/2015, Znikajace miliardy, Centrum Analiz Klubu Jagiellońskiego, http://cakj.pl/wp-content/uploads/2015/09/Znikaj\%C4\%85ce-miliardy.pdf. 
żoną dla małych podatników ${ }^{17}$ lub podatników rozpoczynających działalność). Jednocześnie należy uwzględniać opodatkowanie nie tylko na poziomie spółki kapitałowej, lecz także na poziomie wspólników. Dywidendy podlegają opodatkowaniu w sposób uproszczony, bez uwzględniania kosztów, w wysokości 19\% uzyskanego przychodu (art. 30a ust. 1 pkt 4 u.p.d.f., art. 22 ust. 1 u.p.d.p.). Podatek pobierany przez spółkę kapitałową jako płatnika stanowi ostateczne obciążenie wspólnika z tytułu otrzymanej dywidendy.

Wynika z tego podwójne, w sensie ekonomicznym, opodatkowanie zysków (dochodów) spółki kapitałowej. Całkowite obciążenie podatkowe wynosi zatem $34,39 \%$ (względnie $31,15 \%$ dla małych podatników). Działalność w formie spółki z o.o. wymaga prowadzenia ksiąg rachunkowych w pełnym zakresie i sporządzania (a niekiedy badania) sprawozdań finansowych.

Należy odnotować, że w przypadku udziałowców w formie spółek kapitałowych, w warunkach określonych w art. 22 ust. 4 i n. u.p.d.p., przychód uzyskany z tytułu otrzymania dywidendy jest zwolniony od podatku. Zwalnia się od podatku dochodowego przychody $\mathrm{z}$ dywidend (oraz inne wybrane przychody z tytułu udziału w zyskach osób prawnych), jeżeli spełnione są łącznie następujące warunki:

- uzyskującym tego rodzaju przychody jest spółka podlegająca w Polsce lub w innym państwie należącym do Europejskiego Obszaru Gospodarczego opodatkowaniu podatkiem dochodowym od całości swoich dochodów, bez względu na miejsce ich osiągania (czyli podlegająca nieograniczonemu obowiązkowi podatkowemu),

- spółka uzyskująca tego rodzaju przychody posiada bezpośrednio nie mniej niż 10\% udziałów (akcji) w kapitale spółki zależnej i nie korzysta ze zwolnienia z opodatkowania podatkiem dochodowym od całości swoich dochodów, bez względu na źródło ich osiągania.

W sytuacji spełnienia wskazanych warunków wyeliminowane zostaje - na poziomie udziałowca będącego osobą prawną - podwójne (wielokrotne) opodatkowanie w sensie ekonomicznym. Wypłata zysków na rzecz osoby fizycznej (rezydenta polskiego) powoduje jednak pobór 19\% podatku od dywidendy.

\section{Opodatkowanie dochodów spółek osobowych}

Spółka osobowa (inna niż spółka komandytowo-akcyjna, SKA) ${ }^{18}$ nie jest podatnikiem podatku dochodowego. Obowiązek podatkowy ciąży na wspólnikach spółki osobowej, których przychody (dochody) z udziału w spółce opo-

17 Kryterium klasyfikacji podatników jest oparte na przychodach ze sprzedaży (art. 4a pkt 10 u.p.d.p.). Wartość przychodu ze sprzedaży (wraz z kwotą VAT) małych podatników nie przekroczyła w poprzednim roku podatkowym 1,2 mln euro.

${ }_{18}$ W ustawie używa się pojęcia „spółka niebędąca osobą prawną" (art. 4a pkt 14 u.p.d.p., art. 5 a pkt 26 u.p.d.f.). 
datkowuje się, w zależności od formy prawnej, podatkiem dochodowym od osób fizycznych albo podatkiem dochodowym od osób prawnych (transparencja podatkowa). Wyjątkowo polski ustawodawca zdecydował się na uznanie za podatników CIT spółek komandytowo-akcyjnych, jak również zagranicznych spółek osobowych mających status podatnika zgodnie $\mathrm{z}$ wewnętrznym prawem podatkowym państwa siedziby takich spółek.

Przychody uzyskane przez podatnika z tytułu uczestnictwa w zysku spółki osobowej (innej niż SKA) należy zakwalifikować do przychodów ze źródła pozarolnicza działalność gospodarcza (art. 10 ust. 1 pkt 3 w związku z art. 5b ust. 2 u.p.d.f.). Obowiązuje bowiem zasada, że przychody wspólnika będącego osobą fizyczną z udziału w każdej spółce nieposiadającej osobowości prawnej, bez względu na jej rodzaj, uważa się za przychody z pozarolniczej działalności gospodarczej. Zasada ta w żadnym punkcie ustawy nie jest ograniczana ani modyfikowana ${ }^{19}$. Użycie w art. $5 b$ ust. 2 u.p.d.f. słowa „uważa się", stanowiącego wyraz fikcji prawnej, wynika przede wszystkim z tego, że przychody osiąga spółka osobowa prawa handlowego, a jedynie dla celów podatkowych przypisywane są one jej wspólnikom ${ }^{20}$. W przypadku wspólników będących spółkami kapitałowymi nie ulega wątpliwości, że przychody z udziału w spółce osobowej (innej niż SKA) zalicza się do przychodów z pozarolniczej działalności gospodarczej proporcjonalnie do posiadanego prawa do udziału w zysku (art. 5 ust. 1 u.p.d.p.).

Dochód osiągnięty z tytułu udziału w spółce osobowej (innej niż SKA) stanowi dla jej wspólnika będącego osobą fizyczną dochód z pozarolniczej działalności gospodarczej, podlegający opodatkowaniu według skali podatkowej $(18 \%, 32 \%)$ lub po spełnieniu przez podatnika określonych warunków ustawowych - według stawki 19\% (określanym potocznie jako podatek liniowy). Podatnicy mogą wybrać sposób opodatkowania dochodów z pozarolniczej działalności, składając właściwemu naczelnikowi urzędu skarbowego do dnia 20 stycznia roku podatkowego pisemne oświadczenie o wyborze tego sposobu opodatkowania, a jeżeli podatnik rozpoczyna prowadzenie pozarolniczej działalności gospodarczej w trakcie roku podatkowego - do dnia poprzedzającego dzień rozpoczęcia tej działalności, nie później jednak niż w dniu uzyskania pierwszego przychodu. Pogląd taki jest powszechnie akceptowany w orzecznictwie, a także przez organy podatkowe.

Tym samym wspólnik spółki kapitałowej (będący osobą fizyczną) jest pod względem podatkowym traktowany mniej korzystnie niż wspólnik spółki niebędącej osobą prawną, ponieważ obciążenie podatkowe tego pierwszego jest zasadniczo o 15,39 (względnie 12,15) punktów procentowych wyższe.

19 Tak np. NSA w wyroku z 30 marca 2011 r., sygn. akt II FSK 1925/09.

${ }^{20}$ Szerzej zob. np. M. Jamroży, A. Jamroży, Spółka osobowa prawa handlowego. Aspekty prawno-podatkowe, optymalizacja podatkowa, Wolters Kluwer, Warszawa 2012, s. 131. 


\section{Spółka kapitałowa jako przykład formy hybrydalnej}

W celu połączenia korzyści wynikających z ograniczenia odpowiedzialności w spółce kapitałowej z korzyściami podatkowymi wynikającymi z transparencji podatkowej spółek osobowych (jednokrotność opodatkowania) tworzy się spółki komandytowe, w których komplementariuszem jest spółka kapitałowa (np. spółka z o.o.). Cechy kapitałowe spółki komandytowej wiążą się ze statusem prawnym komandytariusza, który odpowiada w sposób ograniczony za zobowiązania spółki.

Z punktu widzenia prawa podatkowego spółka komandytowa jest transparentna, co oznacza, że nie ona jest podatnikiem podatku dochodowego, lecz jej wspólnicy (komplementariusze i komandytariusze) będący osobami fizycznymi lub prawnymi. Przychody z udziału w takiej spółce komandytowej określa się u każdego podatnika proporcjonalnie do jego prawa w udziale w zysku oraz zasadniczo łączy się z pozostałymi przychodami ze źródeł, z których dochód podlega opodatkowaniu według progresywnej skali podatkowej (art. 8 ust. 1 u.p.d.f. oraz art. 5 u.p.d.p. $)^{21}$.

\section{Możliwy kierunek zmian}

Przyjęty w polskim prawie podatkowym model opodatkowania dochodów z udziału w spółce osobowej nie jest powszechnie stosowany w innych państwach, w szczególności w Europie Środkowo-Wschodniej (zob. tabela 1). Ustawodawstwa podatkowe państw różnią się między innymi pod względem przyznania spółkom osobowym podmiotowości podatkowej. Niektóre systemy podatkowe przyznają prawo wyboru (opcji) sposobu opodatkowania, tj. albo na zasadach obowiązujących spółki kapitałowe albo według zasady transparencji podatkowej.

Tabela 1. Status spółki osobowej w wybranych ustawodawstwach podatkowych

\begin{tabular}{|l|l|}
\hline Transparencja podatkowa & Austria, Dania, Finlandia, Niemcy, Norwegia, Szwecja \\
\hline Podmiotowość podatkowa & $\begin{array}{l}\text { Bułgaria, Chorwacja, Estonia, Hiszpania, Portugalia, Rosja, Rumunia, Litwa, } \\
\text { Ukraina, Węgry }\end{array}$ \\
\hline System mieszany & Francja, Włochy, Szwajcaria, Czechy \\
\hline
\end{tabular}

Przyjęcie w Polsce jednolitego modelu opodatkowania spółek, niezależnie od ich statusu prawnego, ograniczy motywowany względami podatkowymi wybór formy organizacyjno-prawnej prowadzenia działalności gospodarczej. Opodatkowanie, które wypacza decyzje przedsiębiorców w porównaniu z procesem decyzyjnym $\mathrm{w}$ „otoczeniu bez podatków”, prowadzi do dodatkowych kosztów dla podatnika. Obecnie aspekt podatkowy musi być uwzględniany w procesach decyzyjnych, ponieważ różne jest obciążenie podatkowe dochodów, w zależności od wyboru formy prawnej przedsiębiorstwa.

${ }^{21}$ Szerzej zob. rozdział pt. Opodatkowanie dochodów spółek osobowych niniejszego artykułu. 
Dodatkowo nastąpiłoby ujednolicenie zasad określania przychodów i kosztów uzyskania przychodów, determinujących wielkość dochodu (podstawy opodatkowania), z działalności wykonywanej w formie spółek kapitałowych i osobowych. Niejednokrotnie powstają obecnie wątpliwości kwalifikacyjne, np. w odniesieniu do przychodów/kosztów ujawniających się ze stosunków zobowiązaniowych między spółką osobową a jej wspólnikami2 ${ }^{22}$. Nie bez znaczenia jest uniknięcie powtórzeń materii ustawowej zawartej w dwóch odrębnych ustawach (o podatku dochodowym od osób fizycznych i o podatku dochodowym od osób prawnych), a dotyczących źródła - pozarolnicza działalność gospodarcza. Wyodrębnienie jednolitej ustawy o podatku od dochodów z działalności gospodarczej byłoby zabiegiem porządkującym zasady opodatkowania przedsiębiorstw, przyczyniając się do przejrzystości regulacji obejmujących opodatkowanie pozostałych dochodów („osobistych”).

$\mathrm{Z}$ uwagi na zwiększone ryzyko prawne związane z prowadzeniem działalności w formie spółki osobowej ${ }^{23}$ zasady opodatkowania obowiązujące dla spółki komandytowo-akcyjnej, różnicujące ciężar podatkowy w zależności od rodzaju wspólnika, mogłyby zostać rozciągnięte na inne spółki osobowe. Niższy ciężar podatkowy, w założeniu koncepcyjnym, stanowi wynagrodzenie (premię) za wyższe ryzyko prawne związane $\mathrm{z}$ odpowiedzialnością osobistą i nieograniczoną wspólników.

Od 1 stycznia $2014 \mathrm{r}$. SKA ma status podatnika podatku dochodowego od osób prawnych. Podatek dochodowy od dochodów spółki komandytowo-akcyjnej jest pobierany na poziomie spółki i na poziomie jej wspólników. Oznacza to, że SKA w zakresie podatku dochodowego ma taki sam status jak spółki kapitałowe, czyli co do zasady występuje podwójne opodatkowanie w sensie ekonomicznym. Dochody pochodzące z działalności SKA są opodatkowane na poziomie tej spółki według stawki 15\% (dla małych podatników) lub 19\% (dla pozostałych podatników). Późniejsza wypłata dywidendy do wspólników (komplementariuszy i akcjonariuszy) podlega co do zasady opodatkowaniu podatkiem dochodowym (podatkiem dochodowym od osób fizycznych albo podatkiem dochodowym od osób prawnych) według jednolitej stawki 19\%.

Zysk akcjonariusza będącego osobą fizyczną, podobnie jak udziałowca spółki kapitałowej, jest ekonomicznie opodatkowany podwójnie: po raz pierwszy na poziomie spółki (15\% lub 19\% CIT), po raz drugi na poziomie wspólnika $(19 \%$ podatek od dywidendy). Natomiast dywidenda wypłacona akcjonariuszowi bę-

${ }_{22}$ Zob. M. Jamroży, P. Karwat, R. Krasnodębski, Opodatkowanie spółek, Wolters Kluwer, Warszawa 2016, s. 354 i n.

${ }^{23}$ Co do zasady wspólnicy takiej spółki odpowiadają za jej zobowiązania całym swoim majątkiem. Szczegółowe zasady odpowiedzialności wspólników zależą od rodzaju danej spółki osobowej. Wspólnicy spółki jawnej ponoszą odpowiedzialność osobistą, nieograniczoną, solidarną i subsydiarną. Każdy wspólnik odpowiada więc za zobowiązania spółki bez ograniczenia całym swoim majątkiem solidarnie z pozostałymi wspólnikami oraz ze spółką. 
dącemu osobą prawną może podlegać zwolnieniu z podatku, jeżeli np. posiada on przynajmniej $10 \%$ akcji spółki nieprzerwanie przez dwa lata i spełnia pozostale warunki przewidziane w ustawie o podatku dochodowym od osób prawnych ${ }^{24}$.

Z kolei komplementariusz, odpowiadający za zobowiązania spółki całym swoim majątkiem, ma prawo do odliczenia od podatku od dywidendy kwoty podatku zapłaconego przez SKA od własnych dochodów, w części, w jakiej zapłacony przez SKA podatek ekonomicznie obniżył wypłacony komplementariuszowi zysk tej spółki. Co do zasady, oznacza to dla komplementariuszy eliminację podwójnego opodatkowania w sensie ekonomicznym. Komplementariusz ma prawo do kredytu podatkowego, jeżeli zysk wypracowany w danym roku podatkowym przez SKA zostanie mu wypłacony w okresie pięciu kolejnych lat podatkowych, licząc od końca roku następującego po tym, w którym spółka go osiągnęła. Na problemy szczególne, związane np. z uzyskiwaniem zwolnionych dochodów zagranicznych, zwrócono uwagę w innych opracowaniach ${ }^{25}$.

\section{Formy zryczałtowane opodatkowania}

\section{Aktualny stan prawny}

Osoby fizyczne prowadzące samodzielnie działalność gospodarczą albo w formie spółek cywilnych lub jawnych osób fizycznych mają co do zasady możliwość wyboru opodatkowania w formach zryczałtowanych: karty podatkowej albo ryczałtu od przychodów ewidencjonowanych. Formy ryczałtowe zostały zasadniczo oderwane od dochodowości przedsiębiorstwa. Zaletą form zryczałtowanych jest ograniczenie obowiązków sprawozdawczo-ewidencyjnych, w szczególności brak obowiązku prowadzenia ksiąg rachunkowych, księgi przychodów i rozchodów, ewidencji środków trwałych oraz wartości niematerialnych i prawnych. W przypadku ryczałtu od przychodów ewidencjonowanych wystarczy jedynie prosta ewidencja przychodów, a w przypadku karty podatkowej nie ma nawet obowiązku ewidencji przychodów wynikającej z prowadzonej działalności. Wysokość podatku zależy od rodzaju prowadzonej działalności, miejsca jej wykonywania oraz liczby zatrudnionych osób ${ }^{26}$.

${ }^{24}$ Zob. rozdział pt. Opodatkowanie dochodów spółek kapitałowych niniejszego artykułu.

25 Zob. S. Kudert, M. Jamroży, A. Kopeć, Taxation of Partnerships Limited by Shares (SKA), Legislative Objectives, Application Issues and Assessment under the EU Law, „Journal of Management and Financial Sciences” 2015, nr 21(3), s. 45-70; B. Kuźniacki, Krytyczna analiza planów opodatkowania spótek komandytowych i komandytowo-akcyjnych $w$ Polsce jako remedium na unikanie opodatkowania: alternatywne rozwiązanie $w$ definicji komplementariusza, „Przegląd Podatkowy” 2013, nr 10, s. 9-21.

${ }^{26}$ Szerzej zob. np. J. Kulicki, Reforma opodatkowania dochodów [w:] Dylematy reformy systemu podatkowego w Polsce, red. H. Dzwonkowski, J. Kulicki, Wydawnictwo Sejmowe, Warszawa 2016, s. 334. 
Wybór zasad opodatkowania (zasady oparte na opodatkowaniu dochodu lub opodatkowanie zryczałtowane) zależy od rodzaju prowadzonej działalności, jej rozmiaru, liczby osób zatrudnionych, wysokości przychodów i kosztów. Jeśli koszty działalności są niskie w relacji do przychodów (wysoka zyskowność działalności), to wybór form zryczałtowanych jest opłacalny.

\section{Możliwy kierunek zmian}

Formy zryczałtowane powinny być trwałym elementem systemu opodatkowania podatkami dochodowymi. Obok zasady sprawiedliwości, konkretyzowanej przez zasadę powszechności i zasadę równomierności, prostota i zrozumiałość systemu podatkowego są równie ważne. Uzasadnione jest przyznanie prawa wyboru opodatkowania w formie zryczałtowanej szerszemu kręgowi (małych) podatników, niezależnie od formy organizacyjno-prawnej działalności.

Dla mikro i małych przedsiębiorstw rozliczenie podatkowe powinno być proste, aby nie angażować i tak ograniczonych zasobów przedsiębiorcy. Interakcje $\mathrm{z}$ podmiotami otoczenia zewnętrznego, $\mathrm{w}$ tym $\mathrm{z}$ urzędami administracji publicznej, firmami doradczymi czy dostawcami sprzętu i oprogramowania księgowego, nie są konieczne. Korzyści, jakie występują z tytułu opodatkowania np. w formie karty podatkowej, to zarówno bardzo prosty sposób prowadzenia ewidencji podatkowej, jak i stosunkowo niewielki ryczałtowy podatek uiszczany zależnie od przedmiotu prowadzonej działalności gospodarczej ${ }^{27}$.

Wybrana forma opodatkowania wpływa następnie w istotny sposób na funkcjonowanie przedsiębiorstwa. Wpływ ten obejmuje nie tylko wysokość ponoszonych obciążeń podatkowych, ale dotyczy również określonych konsekwencji dla wewnętrznej organizacji podmiotu, w tym konieczności prowadzenia przez podmiot gospodarczy określonych urządzeń księgowych czy rozwoju systemów informacyjnych i informatycznych w firmie.

\section{Zasady ustalania dochodu podatkowego}

\section{Aktualny stan prawny}

Podatnicy są zasadniczo zobowiązani do prowadzenia ewidencji rachunkowej zgodnie z odrębnymi przepisami ${ }^{28} \mathrm{w}$ sposób zapewniający ustalenie wysokości dochodu (straty), podstawy opodatkowania i należnego podatku (art. 9 ust. 1 u.p.d.p., art. 24 ust. 1 u.p.d.f.). Różnice w zasadach prawa bilansowego i prawa podatkowego powodują odmienne traktowanie dla celów rachunkowych

27 Zob. J. Patyk, Zmiany form opodatkowania podmiotów gospodarczych [w:] Kierunki reformy polskiego systemu podatkowego, red. A. Pomorska, Wydawnictwo UMCS, Lublin 2003, s. 306 i n.

${ }_{28}$ Ustawa z 29 września 1994 r. o rachunkowości, t.j. Dz.U. 2016, poz. 1047, ze zm.; dalej: ustawa o rachunkowości. 
i podatkowych przychodów i kosztów. Różnice te mogą mieć charakter trwały lub przejściowy, a ze względu na wpływ na wielkość dochodu - dodatnie lub ujemne ${ }^{29}$.

Nadrzędnymi zasadami rachunkowości, czyli podstawowymi i uniwersalnymi normami postępowania $\mathrm{w}$ rachunkowości, są zasady: wiernego obrazu (true and fair view), memoriałowa, współmierności, ostrożności, kontynuacji działania, ciągłości, istotności i zakazu kompensat. Wynik rachunkowy (księgowy) jest ustalany na podstawie przychodów i kosztów ujętych w księgach rachunkowych zgodnie z nadrzędnymi zasadami rachunkowości. Na wykazywany w księgach rachunkowych wynik brutto (przed opodatkowaniem) składają się:

- wynik działalności operacyjnej (podstawowej i pozostałej),

- wynik operacji finansowych (art. 42 ustawy o rachunkowości).

Zasady prawa bilansowego nie zostały konsekwentnie przejęte przez prawo podatkowe. Wynika to głównie z funkcji, które rachunkowość i prawo bilansowe mają do spełnienia, a także z bieżących uwarunkowań gospodarczych, w tym stanu finansów publicznych. Poniżej zostanie dokonana analiza, w niezbędnym zakresie, respektowania (bądź odrzucania) nadrzędnych zasad rachunkowości w prawie podatkowym. Podstawowe znaczenie mają te nadrzędne zasady rachunkowości, których stosowanie wywiera bezpośredni wpływ na koszty, przychody i wyniki działalności jednostki, tj. zasada memoriałowa, zasada współmierności kosztów i przychodów oraz zasada ostrożności.

Stosowanie w prawie podatkowym zasady memoriałowej dla przychodów $\mathrm{z}$ działalności gospodarczej jest zbieżne z momentem ujmowania przychodów w księgach rachunkowych i w sprawozdaniu finansowym. Za datę powstania przychodu przyjęto co do zasady dzień wydania rzeczy, zbycia prawa majątkowego lub wykonania usługi albo częściowego wykonania usługi, nie później niż dzień wystawienia faktury albo uregulowania należności (art. 12 ust. 3a u.p.d.p., art. 14 ust. 1c u.p.d.f.). Natomiast w innych przypadkach przychód rozpoznawany jest zwykle $w$ dacie otrzymania zapłaty (art. 12 ust. 3e u.p.d.p., art. 14 ust. 1 i u.p.d.f.).

Podobnie jak przychody, również koszty są traktowane w prawie bilansowym wyłącznie według zasady memoriałowej, tzn. niezależnie od okoliczności, czy zostały one opłacone, czy też nie (art. 6 ust. 1 ustawy o rachunkowości). W rachunkowości podstawową cechą kosztu jest fakt zużycia, wykorzystania danego składnika (rozumiany szeroko) z podkreśleniem, że powinno to być zużycie efektywne, czyli pozwalające osiągnąć określony cel. W rachunkowości określenie „poniesiony koszt” jest rozumiane na ogół jednoznacznie jako koszt

29 Szerzej zob. I. Olchowicz, M. Jamroży, Rachunkowość podatkowa. Analiza w zakresie podatku dochodowego od osób prawnych, Difin, Warszawa 2018, s. 52 i n. 
zarachowany, czyli zgodnie z zasadą memoriałową. Nie jest ważne, czy koszt został opłacony, czy też nie.

Zmiany wprowadzone w prawie podatkowym od 1 stycznia 2007 r. odnośnie do zasad ujmowania kosztów zbliżyły w dużym stopniu przepisy prawa podatkowego i prawa bilansowego. Za dzień poniesienia kosztu uzyskania przychodów uważa się dzień, na który ujęto koszt w księgach rachunkowych (zaksięgowano) na podstawie otrzymanej faktury (rachunku), albo dzień, na który ujęto koszt na podstawie innego dowodu w przypadku braku faktury (rachunku), z wyjątkiem sytuacji, gdy dotyczyłoby to ujętych jako koszty rezerw albo biernych rozliczeń międzyokresowych kosztów (art. 15 ust. 4e u.p.d.p., art. 22 ust. 5 d u.p.d.f.). Zastrzeżenie przyjęte dla rezerw, także tych zawartych $\mathrm{w}$ rozliczeniach międzyokresowych kosztów, wynika $\mathrm{z}$ faktu, iż rezerwy tworzone na podstawie zasad rachunkowości nie stanowią kosztów uzyskania przychodów. Wyjątkiem od zasady memoriałowej jest ujęcie dla celów podatkowych niektórych kosztów, takich jak przykładowo ujemne różnice kursowe rozliczane według metody podatkowej, odsetki, wynagrodzenia z tytułu umów cywilnoprawnych.

Rozwinięciem zasady memoriałowej, jeśli chodzi o ustalenie wyniku za dany okres sprawozdawczy, jest zasada współmierności kosztów i przychodów, odnosząca się do wzajemnych relacji między kosztami i przychodami (art. 6 ust. 2 ustawy o rachunkowości). W celu ustalenia wyniku finansowego danego roku obrotowego przyjmuje się przychody i koszty kształtujące ten wynik w danym okresie sprawozdawczym. Przez koszty współmierne z przychodami, czyli te, które przyczyniły się bezpośrednio lub pośrednio do powstania przychodów, należy rozumieć koszty współmierne czasowo i przedmiotowo z przychodami. Wyrazem realizacji zasady współmierności kosztów i przychodów jest ustalenie na koniec okresu zmiany stanu produktów dla działalności produkcyjnej oraz zaliczanie do aktywów lub pasywów danego okresu kosztów lub przychodów dotyczących przyszłych okresów, a także przypadających na ten okres kosztów, które nie zostały jeszcze poniesione według prawa bilansowego. Dotyczy to czynnego ${ }^{30} \mathrm{i}$ biernego ${ }^{31}$ rozliczania międzyokresowego kosztów,

${ }^{30}$ Jednostki dokonują czynnych rozliczeń międzyokresowych kosztów, jeżeli dotyczą one przyszłych okresów sprawozdawczych.

${ }^{31}$ Bierne rozliczenia międzyokresowe kosztów są dokonywane w wysokości prawdopodobnych zobowiązań przypadających na bieżący okres sprawozdawczy, wynikających w szczególności ze świadczeń wykonanych na rzecz jednostki przez kontrahentów jednostki, jeżeli kwotę zobowiązania można oszacować w sposób wiarygodny. Bierne rozliczenia międzyokresowe kosztów wynikają także z obowiązku wykonania, związanych z bieżącą działalnością, przyszłych świadczeń na rzecz pracowników, w tym świadczeń emerytalnych, a także przyszłych świadczeń wobec nieznanych osób, których kwotę można oszacować w sposób wiarygodny, mimo że data powstania zobowiązania nie jest jeszcze znana ( art. 39 ustawy o rachunkowości). 
a także rozliczania międzyokresowego przychodów, tj. przychodów przyszłych okresów.

$\mathrm{W}$ prawie podatkowym kosztów istnieje podział na bezpośrednio i pośrednio związane z przychodami, co jedynie zbliża zasady wynikające z prawa podatkowego do zasad prawa bilansowego. Tego podziału nie należy jednak utożsamiać z podziałem kosztów (dla celów rachunkowości) na bezpośrednie i pośrednie wytworzenia produktów dla celów kalkulacji kosztu wytworzenia produktu. Są to relacje na innych poziomach: $w$ rachunkowości - na poziomie ustalania kosztu wytworzenia produktu, w prawie podatkowym - na poziomie ustalania wyniku $\mathrm{z}$ transakcji sprzedaży.

Zasadniczy jednak problem współmierności kosztów z przychodami stanowią koszty, które z ekonomicznego punktu widzenia mają taki charakter i które są kosztami według zasad rachunkowości, natomiast według prawa podatkowego nie są kosztami uzyskania przychodów przy ustalaniu dochodu do opodatkowania. Pozycje ujęte w katalogu kosztów nieuznawanych podatkowo (art. 16 ust. 1 u.p.d.p., art. 23 ust. 1 pkt 21 u.p.d.f.) nie są wyłącznie pozycjami stanowiącymi koszty sensu stricto, lecz także pozycjami o charakterze wydatków, np. na cele inwestycyjne, w celu uregulowania zobowiązań podatkowych, które z punktu widzenia rachunkowości stanowią jedynie zwiększenie aktywów lub zmniejszenie zobowiązań czy kapitałów.

Ustalając wynik finansowy jednostki, należy uwzględnić skutki zastosowania ostrożnej wyceny, aby wyniku finansowego nie wykazywać w zawyżonej wysokości - chociażby dlatego, aby nie dochodziło do podziału zysku istniejącego tylko „na papierze”. Z ostrożną wyceną wiąże się odmienna interpretacja według prawa bilansowego i prawa podatkowego przede wszystkim dwóch obszarów problemowych: aktualizacji wyceny aktywów oraz tworzenia rezerw na przyszłe zobowiązania. Aktualizacja wyceny aktywów wiąże się z utratą ich wartości. W myśl art. 28 ust. 7 ustawy o rachunkowości trwała utrata wartości zachodzi wtedy, gdy istnieje duże prawdopodobieństwo, że kontrolowany przez jednostkę składnik aktywów nie przyniesie w przyszłości w istotnej części lub w całości przewidywanych korzyści ekonomicznych. Uzasadnia to dokonanie odpisu aktualizującego doprowadzającego wartość składnika aktywów wynikającą z ksiąg rachunkowych do ceny sprzedaży netto, a w przypadku jej braku - do ustalonej w inny sposób wartości godziwej. Utrata wartości może dotyczyć wszystkich aktywów, poczynając od środków trwałych, także i tych w budowie, wartości niematerialnych i prawnych, inwestycji, zapasów, należności, a także waluty obcej. Aktualizacja wyceny na skutek utraty wartości obciąża koszty, a tym samym zmniejsza wynik finansowy jednostki. Są to jednak koszty według prawa bilansowego, a nie według prawa podatkowego.

Natomiast z powodu samego ryzyka utraty wartości nie zmniejsza się podstawy opodatkowania. Wyjątek w tym względzie stanowią należności, których utrata wartości, przy spełnieniu określonych warunków ustawowych, stanowi 
koszt podatkowy. Z podatkowego punktu widzenia za koszty uzyskania przychodów nie uważa się odpisów aktualizujących, z tym że kosztem uzyskania przychodów są odpisy aktualizujące wartość należności, określone w ustawie o rachunkowości, od tej części należności, która była uprzednio zaliczona do przychodów należnych, a ich nieściągalność została odpowiednio uprawdopodobniona (art. 16 ust. 1 pkt 26a u.p.d.p., art. 23 ust. 1 u.p.d.f.). Przede wszystkim musi to być należność wynikająca np. ze sprzedaży, która w momencie powstania przychodu ze sprzedaży została opodatkowana zgodnie z zasadą memoriałową. Uprawdopodobnienie nieściągalności takiej należności powoduje odwrócenie skutków wynikających z uprzednio powstałego zobowiązania podatkowego. Według prawa podatkowego nie uznaje się za koszty uzyskania przychodów również rezerw, jeżeli obowiązek ich tworzenia w ciężar kosztów nie wynika $z$ innych ustaw. Nie są kosztem uzyskania przychodów rezerwy utworzone zgodnie z ustawą o rachunkowości (art. 16 ust. 1 pkt 27 u.p.d.p., art. 23 ust. 1 pkt 22 u.p.d.f.).

\section{Możliwy kierunek zmian}

Zasady wynikające z prawa podatkowego mają często charakter zmienny, doraźny („w skali miesiąca czy roku”), nieobiektywny ekonomicznie, uzależniony od polityki podatkowej realizowanej przez daną ekipę rządową, co znajduje wyraz w permanentnych zmianach przepisów podatkowych lub w zmieniających się ich interpretacjach.

Pewnym środkiem zaradczym może być powiązanie w większym stopniu zasad ustalania wyniku podatkowego z zasadami obowiązującymi w prawie bilansowym. Oderwanie rozpoznawania przychodów lub kosztów dla celów podatkowych od ujęcia rachunkowego powoduje nadmierną kazuistykę przepisów podatkowych. Przy związaniu dochodu (straty) podatkowego z działalności gospodarczej, z uwzględnieniem potrzebnych korekt, z zyskiem (stratą) bilansowym, w razie wątpliwości znajdowałaby zastosowanie interpretacja „w duchu” zasad rachunkowości. Tytułem przykładu, niemieckie prawo podatkowe zawiera tzw. zasadę miarodajności bilansu handlowego dla bilansu podatkowego, będącego podstawą do obliczenia podatku dochodowego (niem. Maßgeblichkeitsprinzip). Ustalanie dochodu podatkowego następuje co do zasady poprzez korektę zysku bilansowego.

Przyjęcie w szerszym zakresie zasady miarodajności pozwoliłoby wyeliminować w warstwie regulacyjnej liczne oczywistości, np. wyłączenie z przychodów zarachowanych należności na poczet dostaw towarów i usług, które zostaną wykonane w następnych okresach sprawozdawczych (art. 12 ust. 4 pkt 1 u.p.d.p., art. 14 ust. 3 pkt 1 u.p.d.f.), a z kosztów uzyskania przychodów - wydatków na nabycie środków trwałych lub wartości niematerialnych i prawnych (art. 16 ust. 1 pkt 1 u.p.d.p., art. 23 ust. 1 pkt 1 u.p.d.f.). Dotyczy to również np. wyceny produkcji zakończonej czy produkcji w toku, pochodnych instrumen- 
tów finansowych oraz praw z nich wynikających. Przyczyniłoby się to również do porządkowania zasad określania przychodów i kosztów dla celów podatkowych, powodując wzmocnienie przejrzystości regulacji obejmujących opodatkowanie dochodów z działalności gospodarczej. Zmniejszyłyby się różnice trwałe jak i przejściowe między wykazywaną w księgach rachunkowych wartością aktywów i pasywów a ich wartością podatkową.

$\mathrm{W}$ związku z innymi funkcjami, które pełni prawo bilansowe i podatkowe, zasada miarodajności ujęcia bilansowego dla celów podatkowych musiałaby doznać ograniczeń. Materia ustaw o podatkach dochodowych obejmowałaby jednak regulacje dotyczące samych różnic, a nie powielała obszernej i złożonej materii ujęcia i wyceny składników majątkowych oraz zobowiązań.

\section{Wycena podatkowa transakcji i innych zdarzeń}

\section{Relacje z podmiotami niepowiązanymi}

W sytuacji odpłatnego zbycia nieruchomości, praw majątkowych i innych rzeczy, a także świadczenia usług organy podatkowe są uprawnione do oszacowania przychodów podatników w żaden sposób ze sobą niepowiązanych w wysokości wartości rynkowej, czyli na podstawie cen rynkowych stosowanych w obrocie rzeczami, prawami lub usługami tego samego rodzaju i gatunku, z uwzględnieniem w szczególności ich stanu i stopnia zużycia oraz czasu i miejsca zbycia albo świadczenia (art. 14 u.p.d.p. i odpowiednio art. 19 u.p.d.f.). Nie stosuje się bardziej sformalizowanych i zobiektywizowanych regulacji dotyczących wyceny transakcji i innych zdarzeń między podmiotami powiązanymi (art. 11 u.p.d.p., art. 25 u.d.p.f.). W razie wątpliwości organ podatkowy jest zobowiązany wpierw do wezwania stron umowy do zmiany określonej umownie wartości lub wskazania przyczyn uzasadniających podanie takiej ceny. Dopiero w razie nieudzielenia odpowiedzi, niedokonania zmiany wartości lub niewskazania przyczyn organ podatkowy powoła biegłego dla określenia wartości rzeczy, prawa majątkowego lub usługi.

Tendencje do coraz szerszego ingerowania $\mathrm{w}$ warunki transakcyjne i szacowania przychodów podatników znalazły odzwierciedlenie we wprowadzonych od 1 stycznia 2018 r. zmianach legislacyjnych, ponieważ wskazana wyżej procedura odnosi się również do przychodów ze świadczenia usług. Ponadto przewidziano, że szacowanie na podstawie art. 14 ust. 1-3 u.p.d.p. stosuje się również do nieodpłatnego zbycia rzeczy lub praw majątkowych na rzecz podmiotu, w którym podatnik lub podatnik wraz z podmiotami powiązanymi posiada udział w wysokości co najmniej 95\% (art. 14 ust. 6 u.p.d.p.) ${ }^{32}$. Regu-

32 Szacunek nie dotyczy nieodpłatnego zbycia rzeczy lub praw organizacjom pożytku publicznego (zob. art. 3 ust. 2 i 3 ustawy z 24 kwietnia 2003 r. o działalności pożytku publicz- 
lacja ta stanowi novum, ponieważ dotychczas na gruncie prawa podatkowego respektowano charakter nieodpłatnych zbyć, dokonywanych np. na podstawie umowy darowizny.

\section{Relacje z podmiotami powiązanymi}

Podatnicy wchodzący w skład (międzynarodowych) grup kapitałowych mogą uzyskiwać korzyści ze współpracy lub z synergii między członkami grupy, które często nie są możliwe do osiągnięcia przez niezależne przedsiębiorstwa znajdujące się $\mathrm{w}$ podobnej sytuacji ${ }^{33}$. Z podatkowego punktu widzenia istotna jest zwłaszcza funkcja podziału dochodu poprzez ceny transferowe. Ustalone ceny transferowe decydują o przychodach i kosztach podmiotów powiązanych, a w konsekwencji też o tym, jak rozkłada się terytorialnie dochód grupy kapitałowej i w jakiej wysokości będzie opodatkowany. Ceny transferowe nie mają natomiast wpływu na łączny dochód przed opodatkowaniem grupy kapitałowej jako całości, pozostający na niezmienionej wysokości, niezależnie od ustaleń cenowych we wzajemnych rozliczeniach.

Wzrost znaczenia cen transferowych prowadzi do wprowadzania kompleksowych regulacji mających na celu przeciwdziałanie erozji podstaw opodatkowania i przenoszeniu zysku. Tendencje regulacyjne są jednoznaczne, zwiększa się złożoność i szczegółowość informacji przekazywanych organom podatkowym, również obejmujących wrażliwe dane finansowe. Rok 2017 otworzył kolejny rozdział w tym zakresie, ze względu na wprowadzenie rozszerzonych obowiązków sprawozdawczo-dokumentacyjnych dla podmiotów powiązanych ${ }^{34}$. Nowe wymogi dokumentacyjne stanowią rezultat wdrożenia do polskiego systemu prawnego wyników prac OECD prowadzonych w ramach projektu BEPS (Base Erosion and Profit Shifting, Erozja bazy podatkowej oraz przenoszenie zysków) ${ }^{35}$. Od 1 stycznia 2017 r. przyjęto, za rekomendacjami zawartymi w działaniu 13 BEPS, koncepcję trójstopniowej dokumentacji cen transferowych:

nego i o wolontariacie, t.j. Dz.U. 2016, poz. 1817, ze zm.) lub równoważnym organizacjom, określonym w przepisach regulujących działalność pożytku publicznego, obowiązujących w innym państwie członkowskim Unii Europejskiej lub Europejskiego Obszaru Gospodarczego.

${ }_{33}$ Przedmiotowe synergie grupy mogą wynikać np. z łącznej siły nabywczej lub korzyści skali, automatyzacji i optymalizacji procesów, połączonych i zintegrowanych systemów informatycznych, zintegrowanego zarządzania, wyższej zdolności kredytowej.

${ }^{34}$ Problematyka korekty dochodu $\mathrm{w}$ wyniku transfer pricing (przerzucania zysków) oraz wymogów dokumentacyjnych znalazła ustawową regulację przede wszystkim w art. 9a i art. 11 u.p.d.p. oraz $w$ art. 25 i art. 25a u.p.d.f.

${ }^{35}$ Cen transferowych i dokumentacji podatkowej dotyczą działania nr 8-10 BEPS (Aligning Transfer Pricing Outcomes with Value Creation) oraz 13 BEPS (Transfer Pricing Documentation and Country-by-Country Reporting). 
- dokumentacja lokalna (local file) - szczegółowe informacje dotyczące transakcji lub innych zdarzeń ujętych w księgach rachunkowych podatnika, zachodzące między nim a podmiotami powiązanymi, jeżeli przychody (koszty) rachunkowe tego podatnika przekroczyły w poprzednim roku podatkowym 2 mln euro ${ }^{36}$,

- dokumentacja grupowa (master file) - informacje o grupie podmiotów powiązanych, w skład której wchodzi podatnik, jeżeli przychody (koszty) rachunkowe tego podatnika przekroczyły w poprzednim roku podatkowym 20 mln euro,

- informacja o grupie podmiotów (country-by-country Report, CbC Report) - informacja w szczególności o wysokości dochodów i zapłaconego podatku oraz miejscach prowadzenia działalności jednostek zależnych oraz zakładów zagranicznych należących do grupy kapitałowej, jeżeli skonsolidowane przychody rachunkowe przekroczyły w poprzednim roku podatkowym $750 \mathrm{mln}$ euro $^{37}$.

Podatnicy, których przychody (koszty) w poprzednim roku podatkowym przekroczyły równowartość $10 \mathrm{mln}$ euro, zobowiązani są ponadto do złożenia uproszczonego sprawozdania w zakresie podatku dochodowego od osób prawnych (CIT/TP, PIT/TP), zawierającego informacje o rodzaju występujących między podmiotami powiązań, posiadanym zagranicznym zakładzie, między innymi o: liczbie podmiotów powiązanych, z którymi podatnik dokonywał transakcji lub innych zdarzeń, głównym przedmiocie działalności, profilu funkcjonalnym, podejmowanej restrukturyzacji, otrzymanych lub wypłaconych z tego tytułu rekompensatach, rodzajach transakcji lub innych zdarzeń zawieranych $\mathrm{z}$ podmiotami powiązanymi (wraz z określeniem ich wartości, procentowego udziału w całkowitych przychodach podatnika i kraju siedziby stron transakcji) ${ }^{38}$.

Kryterium stosowanym w stosunkach międzynarodowych dla badania warunków ustalonych między podmiotami powiązanymi i wynikających z nich cen jest zasada arm's length ${ }^{39}$. Praktyczne stosowanie tej zasady opiera się na

36 Szczegółową zawartość dokumentacji określa rozporządzenie Ministra Rozwoju i Finansów z 12 września 2017 r. w sprawie informacji zawartej w dokumentacji podatkowej w zakresie podatku dochodowego od osób prawnych, Dz.U. poz. 1753.

37 Co do zakresu szczegółowych informacji zob. rozporządzenie Ministra Rozwoju i Finansów z 13 czerwca 2017 r. w sprawie szczegółowego zakresu danych przekazywanych w informacji o grupie podmiotów oraz sposobu jej wypełniania, Dz.U. poz. 1176.

${ }_{38}$ Zob. rozporządzenie Ministra Rozwoju i Finansów z 8 czerwca 2017 r. w sprawie określenia wzoru uproszczonego sprawozdania w zakresie podatku dochodowego od osób prawnych, Dz.U. poz. 1190.

39 W polskiej literaturze zasada ta nazywana jest także zasadą ceny rynkowej, zasadą cen wolnorynkowych czy też zasadą długości ramienia. 
uwzględnianiu kilku ważnych czynników, przede wszystkim: cech charakterystycznych (właściwości) przedmiotu transakcji, cech podmiotów transakcji (czyli w szczególności funkcji spełnianych przez strony transakcji z uwzględnieniem zaangażowania kapitałowego i ponoszonego ryzyka, a także stosowanej strategii gospodarczej), warunków umownych, uwarunkowań ekonomicznych transakcji oraz realizowanej strategii handlowej. Znaczenie każdego z wymienionych czynników zależy od rodzaju analizowanej transakcji i stosowanej metody szacunku (metody porównywalnej ceny niekontrolowanej, metody rozsądnej marży, metody ceny odsprzedaży, metody marży transakcyjnej netto, metody podziału zysków) ${ }^{40}$.

\section{Możliwy kierunek zmian}

Bezsporne jest, że uzasadnionym interesem każdego państwa jest opodatkowanie dochodów podatników, które zostały wypracowane na obszarze podlegającym jego jurysdykcji podatkowej. Państwo, na którego obszarze jurysdykcji dochodzi do zmniejszania wpływów budżetowych, w związku z uzgodnieniem lub narzuceniem warunków nierynkowych, musi wprowadzić mechanizmy umożliwiające korektę dochodu (podatku należnego) ${ }^{41}$.

Restrykcyjność regulacji, nawet uzasadniona zwalczaniem erozji bazy podatkowej ${ }^{42}$, nie powinna nadmiernie ograniczać bezpieczeństwa podatkowego przedsiębiorców. W ocenie autora regulacje podatkowe umożliwiające kwestionowanie, dla celów podatkowych, ustaleń dokonywanych między podmiotami niepowiązanymi stanowią już nadmierną ingerencję w swobodę prowadzenia działalności gospodarczej. Możliwość formułowania zarzutu odbiegania ustalonego wynagrodzenia od cen rynkowych na podstawie art. 14 ust. 1-3 u.p.d.p. (odpowiednio art. 19 ust. 1-3 u.p.d.f.) pomija całkowicie okoliczność, że określone świadczenia nie muszą znajdować się w obrocie rynkowym, a jeżeli występuje obrót rynkowy, to niezmiernie trudno jest ustalić porównywalne świadczenie. Odwołanie się zatem do wartości rynkowej, ustalanej na podstawie cen rynkowych stosowanych $\mathrm{w}$ obrocie rzeczami, prawami lub usługami tego samego rodzaju i gatunku, z uwzględnieniem w szczególności ich stanu i stopnia zużycia oraz czasu i miejsca zbycia albo świadczenia, jest anachronizmem ${ }^{43}$. Jest wiele elementów różnicujących świadczenia tego samego rodzaju (np. zakres i jakość świadczeń, podział ryzyka i odpowiedzialności stron

${ }^{40}$ Szerzej zob. np. z dalszymi odesłaniami Dokumentacja podatkowa cen transferowych, red. M. Jamroży, ODDK, Gdańsk 2014, s. 102 i n.

${ }^{41}$ Zob. np. M. Jamroży, Tax Risk Management in the Area of Transfer Pricing [w:] Business and Non-Profit Organizations Facing Increased Competition and Growing Customers Demands, red. A. Nalepka, A. Ujwary-Gil, Wyższa Szkoła Biznesu - National-Louis University, Nowy Sącz 2013, s. 311-321.

42 Zob. rozdział pt. Erozja bazy podatkowej niniejszego artykułu.

${ }^{43} \mathrm{~W}$ prawie podatkowym nie używa się pojęcia wartości godziwej. 
transakcji, realizowana strategia gospodarcza). Cena rynkowa nie stanowi też zazwyczaj określonej wartości stałej (punktowej), a raczej mieści się w określonym przedziale cenowym.

W przypadku szacowania przychodów wynikających z tego rodzaju transakcji nie odwołano się do metod szacunku dochodów podatników powiązanych, tj. metody porównywalnej ceny niekontrolowanej, ceny odsprzedaży, rozsądnej marży, które ograniczają w istotnym stopniu dowolność w działaniu organów podatkowych. Przedsiębiorcy ze sobą niepowiązani nie powinni być narażeni na łatwiejszą ingerencję ze strony organów podatkowych w warunki przeprowadzanych transakcji, ze względu na dużo mniej złożoną procedurę szacowania przez organ podatkowy przychodów, bez konieczności stosowania metod szacunku przewidzianych w art. 11 ust. 2 i 3 u.p.d.p. (art. 25 ust. 2 i 3 u.p.d.f.). W ocenie autora ingerencja w mechanizmy rynkowe (obrót rynkowy) dokonywany między podmiotami niepowiązanymi, zainteresowanymi maksymalizacją zysku, jest działaniem regulacyjnie za daleko idącym.

Również polityki cen transferowych stosowanej przez podmioty powiązane nie należy oceniać mechanicznie, według utartego wzorca przerzucania dochodów. Pewna swoboda decyzyjna w zakresie polityki cen transferowych wynika $z$ tego, że ceny rynkowe danego dobra kształtują się w pewnym przedziale wartości. Poziom rynkowy cen (marż itp.) determinuje wiele czynników, takich jak indywidualne cechy danego dobra, profile funkcjonalne podmiotów uczestniczących w transakcji, położenie i cechy rynku, natężenie konkurencji czy też warunki transakcyjne. Przez podmioty powiązane są podejmowane działania przynoszące wprawdzie korzyści podatkowe, ale opierające się głównie na powodach pozapodatkowych (biznesowych), dotyczących usytuowania geograficznego poszczególnych fragmentów działalności biznesowej grupy, związanego chociażby z dostępem do kapitału ludzkiego, obniżeniem kosztów działalności, podziałem obszarów działalności bądź zapewnieniem pewności obrotu $^{44}$. Jednak możliwości podmiotów powiązanych w zakresie swobodnego kształtowania stosunków prawnych nie powinny być nadużywane w celu minimalizacji zobowiązania podatkowego.

Wprowadzone zmiany prawne w zakresie szczegółowych wymogów dokumentacyjnych są uzasadnione, w szczególności dla dużych przedsiębiorców, mimo że skutkują znacznym wzrostem obciążeń administracyjnych i finansowych (np. w odniesieniu do sporządzania analiz danych porównawczych). Niewątpliwie istnieje potrzeba lepszego dopasowania standardu arm's length do realiów rynkowych, tj. postępującego skomplikowania transakcji i często unikatowości wymienianych dóbr, oraz poprawy operacyjności istniejących metod szacunku. W razie niemożności identyfikacji transakcji porównywalnych w szerszym zakresie (nie tylko subsydiarnie) należy dopuścić stosowanie

${ }^{44}$ W tym kontekście zob. też wyrok NSA z 16 lutego 2000 r., sygn. akt I SA/Gd/790/99. 
metod zysku transakcyjnego, z uwzględnieniem łańcucha tworzenia wartości dodanej. Działaniem mogącym mieć, przynajmniej pośrednio, pozytywny wpływ na kwestie związane z cenami transferowymi jest rozwój sprawozdawczości finansowej w kontekście wypracowania powszechnych standardów pozwalających na sprawniejsze uchwycenie (zmian) stanu zasobów, w tym niematerialnych.

\section{Restrukturyzacja biznesowa}

\section{Aktualny stan prawny}

W ramach restrukturyzacji biznesowej przedsiębiorcy kształtują formę bądź strukturę prowadzenia działalności w taki sposób, aby poprawić jej efektywność (po opodatkowaniu) w porównaniu z rozwiązaniami dotychczasowymi. Określony cel restrukturyzacyjny można zwykle osiągnąć w różny sposób, a każdy z nich może pociągać za sobą odmienne obciążenia podatkowe. Generalizując, spośród transakcji restrukturyzacyjnych można wyodrębnić:

- transakcje związane z sukcesją podatkową i zasadniczo powodujące odroczenie opodatkowania,

- transakcje niezwiązane z sukcesją podatkową i zasadniczo powodujące ujawnienie cichych rezerw (względnie obciążeń) zawartych w zbywanych składnikach majątkowych (np. transakcje sprzedaży przedsiębiorstwa, wnoszenie aportów, likwidacja działalności spółki kapitałowej).

Do grupy transakcji skutkujących odroczeniem opodatkowania należy zaliczyć w szczególności aport przedsiębiorstwa lub zorganizowanej części przedsiębiorstwa, wymianę udziałów, przekształcenia formy prawnej spółek, połączenia spółek bądź podziały spółek (w określonych warunkach). W ramach procesów restrukturyzacyjnych spółek kapitałowych, w szczególności $\mathrm{w}$ transakcjach związanych $\mathrm{z}$ sukcesją podatkową należy dokonywać oceny skutków podatkowych zarówno na poziomie spółki kapitałowej, jak i na poziomie wspólników ${ }^{45}$.

W procesach reorganizacyjnych lub transakcjach postrestrukturyzacyjnych w celu weryfikacji ustalonych warunków należy stosować zasadę arm's length ${ }^{46}$, czyli odwołać się do warunków, jaki przyjęłyby niezależne podmioty dokonujące transakcji w porównywalnych warunkach. W polskich (enigmatycznych) regulacjach ${ }^{47}$ przyjmuje się, że przez restrukturyzację działalności rozumie

${ }^{45}$ Szerzej na temat skutków podatkowych poszczególnych rodzajów działań reorganizacyjnych zob. M. Jamroży, P. Karwat, R. Krasnodębski, Opodatkowanie spółek, op. cit.

${ }_{46}$ Zob. rozdział pt. Relacje z podmiotami niepowiązanymi niniejszego artykułu.

47 Zob. $\$ 23$ a rozporządzenia Ministra Finansów z 10 września 2009 r. w sprawie sposobu i trybu określania dochodów osób prawnych w drodze oszacowania oraz sposobu i trybu 
się przeniesienie między podmiotami powiązanymi istotnych ekonomicznie funkcji, aktywów lub ryzyk. W toku badania organy podatkowe powinny uwzględnić przyczyny gospodarcze dokonania restrukturyzacji działalności, oczekiwane korzyści z restrukturyzacji, w tym efekt synergii, oraz opcje realistycznie dostępne dla podmiotów powiązanych uczestniczących w restrukturyzacji. Organy podatkowe sprawdzają prawidłowość ustalenia prawa do wynagrodzenia podmiotu powiązanego oraz wartości wynagrodzenia podmiotu powiązanego, biorąc pod uwagę w szczególności opcje realistycznie dostępne dla podmiotów uczestniczących w tej restrukturyzacji.

\section{Możliwy kierunek zmian}

Aktualne regulacje dotyczące opodatkowania działań (procesów) restrukturyzacyjnych są fragmentaryczne oraz mało czytelne (różne umiejscowienie regulacji). Przykładowo, brak jest pewności co do skutków podatkowych przekształceń spółek osobowych w spółki kapitałowe (brak regulacji, wątpliwości co do stosowania analogii). Używane jest pojęcie „wartości” w odniesieniu do transferów aktywów w ramach restrukturyzacji bez sprecyzowania, o jaką wartość chodzi (bilansową czy rynkową), co ma potencjalnie wpływ na wielkość przychodów (kosztów) podatkowych. Podatnicy nie mają prawa wyboru między odroczeniem opodatkowania a ujawnieniem „cichych rezerw” zawartych w składnikach majątkowych i ich opodatkowaniem na dzień dokonania danej transakcji restrukturyzacyjnej. Warto zaznaczyć, że z punktu widzenia uczestników transakcji restrukturyzacyjnej transakcje neutralne podatkowo nie muszą być korzystniejsze od transakcji powodujących powstanie dochodu do opodatkowania, ponieważ te pierwsze cechuje kontynuacja wyceny składników majątkowych i zasad amortyzacji. Wreszcie, ustawy podatkowe milczą na temat konkretnych zasad wyceny procesów restrukturyzacyjnych dla potrzeb cen transferowych.

Aby wyeliminować wskazane deficyty regulacyjne w zakresie ujęcia i wyceny dla celów podatkowych, uzasadnione jest przyjęcie kompleksowej regulacji normatywnej, dotyczącej wyłącznie opodatkowania procesów restrukturyzacyjnych. Nie bez znaczenia będzie uniknięcie powtórzeń przepisów zawartych obecnie w dwóch odrębnych ustawach (o podatku dochodowym od osób fizycznych i o podatku dochodowym od osób prawnych), odnoszących się do skutków podatkowych zdarzeń restrukturyzacyjnych. Wyodrębnienie materii w szczególnej ustawie o opodatkowaniu restrukturyzacji biznesowych byłoby również zabiegiem porządkującym zasady opodatkowania, przyczyniając się do przejrzystości regulacji zdarzeń nieperiodycznych („wyjątkowych”).

eliminowania podwójnego opodatkowania osób prawnych w przypadku korekty zysków podmiotów powiązanych, Dz.U. nr 160, poz. 1268, ze zm. 


\section{Podsumowanie}

Czas już dojrzał do reformy systemu opodatkowania dochodów z działalności gospodarczej. Od lat wycinkowo nowelizuje się („uszczelnia”) prawo podatkowe, co przeczy stabilizacji systemu podatkowego. Permanentne nowelizacje ustaw podatkowych, wprowadzanie zmian do „właśnie” przyjętych rozwiązań legislacyjnych nie sprawią, że proces erozji bazy podatkowej zostanie zahamowany, a ocena systemu podatkowego przez przedsiębiorców ulegnie poprawie. Rozwiązania legislacyjne w zakresie opodatkowania dochodów z działalności gospodarczej cechuje nadmierna kazuistyka, a przyjęte zasady podatkowe są nieczytelne i stosowane niekonsekwentnie, co tylko potęguje spory interpretacyjne.

Istnieje zatem potrzeba gruntownej przebudowy systemu opodatkowania dochodów z działalności gospodarczej. W artykule sformułowano, punktując jednocześnie ułomności regulacyjne, propozycje rozwiązań systemowych w zakresie:

- eliminacji dualizmu w opodatkowaniu dochodów spółek handlowych, z uwzględnieniem systemu kredytu podatkowego dla wspólników ponoszących odpowiedzialność bez ograniczenia całym swoim majątkiem za zobowiązania spółki,

- poszerzenia zastosowania form ryczałtowych opodatkowania dla mikro i małych przedsiębiorców, skutkujących minimalizacją obciążeń ewidencyjno-sprawozdawczych,

- zmiany zasad ustalania dochodu podatkowego, przez ściślejsze powiązanie z wynikiem finansowym jako pozycją wyjściową dla dokonania korekt podatkowych,

- wyceny podatkowej transakcji lub innych zdarzeń, przez zniesienie możliwości ingerencji w warunki transakcyjne między podmiotami niepowiązanymi, a poszerzając metody wyceny transakcji (np. w zakresie dóbr niematerialnych) między podmiotami powiązanymi,

- opodatkowania restrukturyzacji biznesowych, przez przyjęcie kompleksowej (odrębnej) regulacji, obejmującej ogóle zasady ujęcia i wyceny dla celów podatkowych, a także rozwiązania szczegółowe w odniesieniu do wybranych zdarzeń restrukturyzacyjnych; podatnikom należy przyznać prawo wyboru między zastosowaniem mechanizmu odroczenia opodatkowania (powiązanego z kontynuacją wyceny składników majątkowych) a ujawnieniem i opodatkowaniem nadwyżek wartości na dzień wystąpienia zdarzenia restrukturyzacyjnego (bez kontynuacji wyceny składników majątkowych).

Sformułowane postulaty mogą posłużyć za przyczynek do dalszej pogłębionej dyskusji nad reformą opodatkowania dochodów z działalności gospo- 
darczej, tym bardziej że w literaturze formułowane są różne postulaty de lege ferenda w zakresie opodatkowania dochodów w Polsce. Na przykład J. Kulicki zaproponował między innymi odmienny niż obecnie podział źródeł przychodów, w celu ujednolicenia zasad opodatkowania dochodów wszystkich podmiotów, bez względu na ich formę prawną oraz rodzaj źródła przychodów. Przychody działalności gospodarczej mogłyby zostać włączone albo do przychodów z aktywności zawodowej jako przychody z pracy na własny rachunek, albo stać się elementem aktywności inwestycyjnej jako odrębnego źródła przychodów. Działalność gospodarcza zaliczana byłaby do przychodów z aktywności zawodowej podatnika wówczas, gdy prowadzona byłaby jednoosobowo, bez zatrudniania pracowników, z wyjątkiem członków rodziny pozostających we wspólnym gospodarstwie domowym, bez względu na wielkość osiąganych przychodów, o ile podatnik nie uzna, że chce rozliczać się dla potrzeb podatkowych według zasad ustalonych dla aktywności inwestycyjnej (prawo wyboru) ${ }^{48}$. Koncepcja reformy podatkowej powinna uwzględniać w równym stopniu rekomendacje wynikające $z$ teorii optymalnego opodatkowania, przez oparcie zmian w prawie podatkowym na strategicznych celach rozwojowych, legitymizacji poboru podatków, a także minimalizacji kosztów procesu fiskalnego.

\section{Bibliografia}

Brzeziński B., Reformy podatkowe - teoria i doświadczenia polskie [w:] Systemowa reforma podatków dochodowych, red. B. Brzeziński, W. Nykiel, C.H. Beck, Warszawa 2009.

Dokumentacja podatkowa cen transferowych, red. M. Jamroży, ODDK, Gdańsk 2014.

Dylematy reformy systemu podatkowego w Polsce, red. H. Dzwonkowski, J. Kulicki, Wydawnictwo Sejmowe, Warszawa 2016.

Gałuszka J., Korupcja i szara strefa wobec polityki gospodarczej państwa [w:] Konsekwencje zmiany obciążen podatkowych $w$ Polsce, red. J. Głuchowski, K. Piotrowska-Marczak, J. Fila, Difin, Warszawa 2013.

Główny Urząd Statystyczny, Zweryfikowany szacunek produktu krajowego brutto za lata 2010-2015, https://stat.gov.pl/obszary-tematyczne/rachunki-narodowe/roczne-rachunki-narodowe/zweryfikowany-szacunek-produktu-krajowego-brutto-za-lata-2010-2015,9,2.html.

Grądalski F., System podatkowy w świetle teorii optymalnego opodatkowania, Oficyna Wydawnicza SGH, Warszawa 2006.

Grądalski F., Teoretyczne aspekty racjonalizacji systemu podatkowego [w:] Dorobek ekonomii, finansów i nauk o zarządzaniu oraz jego praktyczne wykorzystanie na przełomie XX i XXI wieku, red. R. Bartkowiak, J. Ostaszewski, Oficyna Wydawnicza SGH, Warszawa 2012.

48 Zob. J. Kulicki, Reforma opodatkowania dochodów, op. cit., s. 348 i n. 
Ickiewicz J., Podatki. Składki. Opłaty. Fiskalne obciążenia działalności gospodarczej, Oficyna Wydawnicza SGH, Warszawa 2014.

Jamroży M., Jamroży A., Spółka osobowa prawa handlowego. Aspekty prawno-podatkowe, optymalizacja podatkowa, Wolters Kluwer, Warszawa 2012.

Jamroży M., Tax Risk Management in the Area of Transfer Pricing [w:] Business and Non-Profit Organizations Facing Increased Competition and Growing Customers' Demands, red. A. Nalepka, A. Ujwary-Gil, Wyższa Szkoła Biznesu - National-Louis University, Nowy Sącz 2013, http://konferencja.jemi.edu.pl/files/monografie/monografia_vol12.pdf.

Jamroży M., Karwat P., Krasnodębski R., Opodatkowanie spółek, Wolters Kluwer, Warszawa 2016.

Jamroży M., Kudert S., Optymalizacja opodatkowania dochodów przedsiębiorstw, Wolters Kluwer, Warszawa 2013.

Kudert S., Jamroży M., Kopeć A., Taxation of Partnerships Limited by Shares (SKA): Legislative Objectives, Application Issues and Assessment under the EU Law, "Journal of Management and Financial Sciences" 2015, nr 21(3), http://kolegia.sgh.waw. pl/pl/KZiF/czasopisma/Journal_of_Management_and_Financial_Sciences_JMFS/ Documents/JMFS\%2021.pdf.

Kulicki J., Reforma opodatkowania dochodów [w:] Dylematy reformy systemu podatkowego $w$ Polsce, red. H. Dzwonkowski, J. Kulicki, Wydawnictwo Sejmowe, Warszawa 2016.

Kuźniacki B., Krytyczna analiza planów opodatkowania spółek komandytowych i komandytowo-akcyjnych $w$ Polsce jako remedium na unikanie opodatkowania: alternatywne rozwiązanie $w$ definicji komplementariusza, „Przegląd Podatkowy” 2013, nr 10.

Ministerstwo Finansów, Informacja dotycząca rozliczenia podatku dochodowego od osób prawnych za 2016 rok, http://www.finanse.mf.gov.pl/documents/766655/6153845/ Informacja.

Olchowicz I., Jamroży M., Rachunkowość podatkowa. Analiza w zakresie podatku dochodowego od osób prawnych, Difin, Warszawa 2018.

Patyk J., Zmiany form opodatkowania podmiotów gospodarczych [w:] Kierunki reformy polskiego systemu podatkowego, red. A. Pomorska, Wydawnictwo UMCS, Lublin 2003, s. 306-309.

Piekarz R., Miarkowski A., Raport 1/2015, Znikajace miliardy, Centrum Analiz Klubu Jagiellońskiego, http://cakj.pl/wp-content/uploads/2015/09/Znikaj\%C4\%85ce-miliardy.pdf.

Pietrewicz M., Felis P., Jamroży M., Szlęzak-Matusewicz J., Przesłanki i kierunki zmian w polskim systemie podatkowym - wybrane zagadnienia [w:] Rozwój nauki o finansach. Stan obecny i pożądane kierunki jej ewolucji, red. J. Ostaszewski, E. Kosycarz, Oficyna Wydawnicza SGH, Warszawa 2014. 


\section{Akty prawne}

Dyrektywa Rady (UE) 2016/1164 z 12 lipca 2016 r. ustanawiająca przepisy mające na celu przeciwdziałanie praktykom unikania opodatkowania, które mają bezpośredni wpływ na funkcjonowanie rynku wewnętrznego, Dz.Urz. UE L 193 z 19 lipca 2016 r., s. 1.

Rezolucja Parlamentu Europejskiego z 10 lutego 2010 r. w sprawie wspierania dobrych rządów w dziedzinie opodatkowania, 2009/2174(INI), Dz.Urz. UE C 341 z 16 lutego 2010 r., s. 29.

Rezolucja z 8 czerwca 2010 r. w sprawie koordynacji zasad dotyczących przedsiębiorstw zagranicznych i niedostatecznej kapitalizacji w Unii Europejskiej (2010/C 156/01), Dz.Urz. UE C 156 z 6 czerwca 2010 r., s. 1.

Zalecenia Komisji 2012/772/UE z 6 grudnia 2012 r. w sprawie agresywnego planowania podatkowego, Dz.Urz. UE L 338 z 12 grudnia 2012 r., s. 41.

Ustawa z 26 lipca 1991 r. o podatku dochodowym od osób fizycznych, t.j. Dz.U. 2016, poz. 2032, ze zm.

Ustawa z 15 lutego 1992 r. o podatku dochodowym od osób prawnych, t.j. Dz.U. 2016, poz. 1888 , ze zm.

Ustawa z 29 września 1994 r. o rachunkowości, t.j. Dz.U. 2016, poz. 1047, ze zm.

Ustawa z 24 kwietnia 2003 r. o działalności pożytku publicznego i o wolontariacie, t.j. Dz.U. 2016, poz. 1817, ze zm.

Rozporządzenie Ministra Finansów z 10 września 2009 r. w sprawie sposobu i trybu określania dochodów osób prawnych w drodze oszacowania oraz sposobu i trybu eliminowania podwójnego opodatkowania osób prawnych w przypadku korekty zysków podmiotów powiązanych, Dz.U. nr 160, poz. 1268, ze zm.

Rozporządzenie Ministra Rozwoju i Finansów z 8 czerwca 2017 r. w sprawie określenia wzoru uproszczonego sprawozdania w zakresie podatku dochodowego od osób prawnych, Dz.U. poz. 1190.

Rozporządzenie Ministra Rozwoju i Finansów z 13 czerwca 2017 r. w sprawie szczegółowego zakresu danych przekazywanych w informacji o grupie podmiotów oraz sposobu jej wypełniania, Dz.U. poz. 1176.

Rozporządzenie Ministra Rozwoju i Finansów z 12 września 2017 r. w sprawie informacji zawartej w dokumentacji podatkowej w zakresie podatku dochodowego od osób prawnych, Dz.U. poz. 1753.

\section{Pozostałe}

Http://www.oecd.org/tax/beps-2015-final-reports.htm.

Http://www.finanse.mf.gov.pl/budzet-panstwa/wplywy-budzetowe.

Http://www.rp.pl/Budzet-i-Podatki/303169813-Ponad-40-mld-zl-luki-w-podatku-CIT.html\#ap-1.

Wyrok NSA z 30 marca 2011 r., sygn. akt II FSK 1925/09.

Wyrok NSA z 12 stycznia 2012 r., sygn. akt II FSK 2068/10.

Wyrok NSA z 8 marca 2016 r., sygn. akt II FSK 4000/1

Wyrok NSA oddział w Gdańsku z 16 lutego 2000 r., sygn. akt I SA/Gd/790/99. 